\title{
The Study Of Islamic Fund Performance In Indonesia: A Meta Analysis
}

\author{
Eky Ermal $\mathrm{M}^{1 *}$, Vina Arnita ${ }^{2}$, Widyana Verawaty Siregar ${ }^{3}$, Hazmanan Khair Pasaribu ${ }^{4}$ \\ \{ekyermal@staff.uma.ac.id*\} \\ ${ }^{1}$ Universitas Medan Area, Fakultas Ekonomi dan Bisnis, Indonesia \\ ${ }^{2}$ Universitas Pembangunan Pancabudi, Fakultas Sosial Sains, Indonesia \\ ${ }^{3}$ Universitas Malikussaleh, Department of Management, Indonesia \\ ${ }^{4}$ Universitas Muhammadiyah Sumatera Utara, Fakultas Ekonomi dan Bisnis, Indonesia
}

\begin{abstract}
This paper focuses on risk-return performance analysis, comparative between Islamic funds and indices against their conventional benchmark. This study do not show the empirical result study, on the other hand this study simply evaluate the performance of Islamic fund in Indonesia using analysis of Islamic paper in Indonesia. Following international result, the objective of this study is to know the performance Islamic investment risk-return profile and risk adjusted return measures whether Islamic funds outperform, underperform, or similar performance against the conventional benchmark. This perspectives study showed inconsistency results while some evidences analyzed in Indonesia do not supporting the portfolio theory. The stakeholder might be able to be selecting their consideration of investment decision by using the meta analysis of this study. Therefore, from this conceptual paper the Indonesian perspective of Islamic index describes performance different than conventional benchmarking.
\end{abstract}

Keywords: Islamic Index, Jakarta Islamic Index, Performance, Indonesian Stock Exchange

\section{Introduction}

We know that Indonesia is a country with the biggest population Muslims in the world. The reasons why Islamic fund growth better because the Indonesian people highly appreciate on their investment. The development of Islamic capital market in Indonesia was started more than a decade ago. The capital market in Indonesia appreciates this phenomenon because of investment demand based on Islamic investment. Furthermore, Albaity and Ahmad (2008) explain that Islamic investment basically is adopted based on Islamic principles, such as "Mu'amalat" which is known as a stock exchange transactions willing in line with Islamic principles.

The potential difference feature of Islamic capital market activities is adopting the principles of Islam, whereas the conventional benchmark is not applied (Dewi and Ferdian, 2009). Islamic Finance in this term is an Islamic investment adopt with Shariah requirements. Islamic stocks are screened to ensure that index that they are consistent with Islamic rule. The screening in Islamic Law is aimed that corporation who applied is compliant with Shariah activities and requirements. In this context, the investors who adopt Islamic finance should consist with their value and personal beliefs that appropriate with Islamic law. (Snoussi et al., 2012).

Most of authors focus on prohibitions of Islamic finance, such as Gharar (doubtful transactions or uncertainty), Riba (Interest or Usury), Maysir (speculation or gambling) 
and Haram (Forbidden). Therefore, these four elements are clearly not allowed in Islamic finance (Ahmad and Ibrahim, 2002, Abdelsalam et al., 2014).

Further, Indonesia Stock Exchange gives more explanation about the principles of Islamic finance. Business related to gambling activities (Maysir), Riba and Gharar is a group of stock that excluded on the Shariah index in Indonesia. This rule is insisted by Indonesia Shariah council and Indonesia Financial Services Authority in law Number IX.a.13 about the Shariah capital market (IDX, 2010). Due to Islamic finance and investment, Riba is clearly as prohibition feature. This is explained in the Holy Qur'an that Riba known as earning from the interest that inflict on side party in business. Therefore, Islam focuses instead on partnerships and risk-sharing (Ghoul and Karam, 2007). Moreover Lyn and Zychowicz (2010) argues in their statement related to Islamic investment as define as an ethical investment, for example; is religious beliefs related well with investment decision process or do Investors sacrifice their return as their faith. Then, to address this issue, this study of Islamic performance investment is expected given answer to the party who need information about this performance study.

Islamic Economic is relatively not denied on profit, private ownership, or market forces. Islamic economics are also focus on profit for the future, but in "Halal" permitted way. In this context, Islamic economics is not total freedom rule. As long as the business activities follow the rule of Islamic screening or element, then the business can be accepted as Islamic economics (Forte and Miglietta, 2011). From this background related islamic studies, Therefore, the objective of this study is to analyse and observing the performance of the Islamic study, particularly in the investment field. Does it economic value include for religious beliefs into the investment-decision process? Is it the best decision for investors willing to sacrifice satisfactory economic returns by making ethically investing decisions based on their faith? To address this issue this study is expected gives a more comprehensive answer of performance of Islamic fund in Indonesia.

The awarness of islamic fund in Indonesia until 2018 showed 198 numbers of mutual fund and three indexes in the capital market (JII, ISSI and JII70). The day of a launched of JII was on 3 July 2000. As a barometer for Islamic investment in Indonesia, JII reflected Islamic stock conditions in Indonesia. Then Indonesia Stock Exchange collaborated with Danareksa Investment Management developed this index as a benchmark based on Islamic Shariah stock exchange. Furthermore, for regulation purposes Indonesia Shariah Council collaborate with Indonesia Financial Services Authority made some criteria to fulfill Shariah principles. As mentioned in background of study, four principles of Islamic screening are compulsory to apply. JII consist of 30 of stock that selected with Islamic principle. Therefore, Jakarta Islamic index will be reviewed and monitoring twice a year every six months.

Islamic instrument is expected to serve benefit from diversification of portfolio to enrich global capital market activities. Related to the performance, the most investors can find the easiest and efficient way to improve return is to invest in Islamic indices which are more transparent with lower risks (Ho et al., 2013). Thus, this concept is recognized as an important design parameter for Islamic investment performance both of the investor's perspective and academic idea. However, the development of Islamic fund in Indonesia showed different evidences, with regards to Islamic Index in Indonesia, Figure 1 and Figure 2 below shows the one year period movement of the JII and ISSI Index. This plot clearly shows the increasing trend of the JII and ISSI Index in several years. 


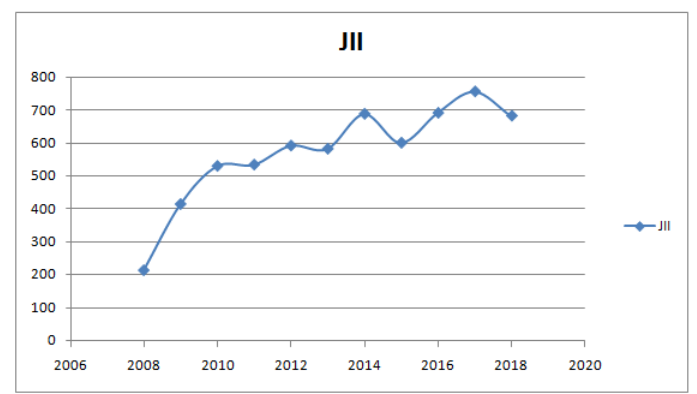

Fig.1. the JII monthly closing price index from January 2014 to December 2014

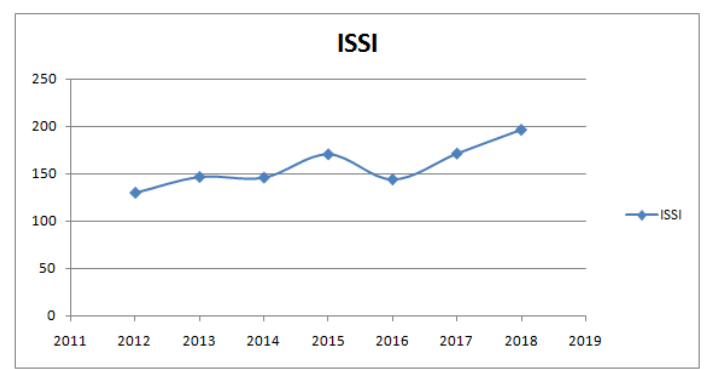

Fig.2. the ISSI monthly closing price index from January 2014 to December 2014

This study furthermore wants to explore to show the value of Islamic Indices (JII and ISSI) and other Islamic investment funds-compare with market benchmark. Some of them using mostly the traditional index method such as (Jensen alpha, Sharpe and Treynor Ratio). The Jakarta Composite Index (JCI) as recognized as a market conventional index. This market index is aimed as a benchmark for the performance comparison study. As a benchmark for Islamic investment index fund and also as the main market barometer, the Jakarta Composite Index (JCI) is attempted used as a conventional index in this study. The JCI serves as an indicator of the performance of the Indonesian economy. Thus, the JCI is the important indicator of local business and market conditions.

\section{Literature Review}

The financial return is as an important aspect of investment process. Markowitz (1952), in his portfolio theory describes the aim of investors is to maximize their wealth. Furthermore, Zulkafli., et, al. (2017) identify from Markowitz perspective that the portfolio theory describes the importance of diversification in reducing risks without sacrificing returns, this portfolio effect is an output from the correlation of returns among securities.

Albaity and Ahmad (2008) argue that traditional investors' focuses on their diversifying investment to maximize return and get purposes minimum risk. Hickman et al. (1999) indicate that the lower the correlations of returns between securities, the higher the reduction of risk. Therefore, a well diversified portfolio will only be affected by an economy-wide risks or market risks. More existing empirical literature about portfolio study, however, finds three results of performance, Outperform, Similar 
performance and Underperform. Table 1 showed the results of several Islamic fund performances.

Table 1. Several Results of the studies of Islamic Performance.

\begin{tabular}{|c|c|}
\hline Authors & Results \\
\hline $\begin{array}{l}\text { Sundoro and } \\
\text { Handayani } \\
(2018)\end{array}$ & $\begin{array}{l}\text { The result showed inconsistency, the islamic fund } \\
\text { performance are diverse when compared to the } \\
\text { benchmarking }\end{array}$ \\
\hline Huda (2018) & $\begin{array}{l}\text { There were no differences performance significant } \\
\text { mutual funds stocks of conventional and Islamic }\end{array}$ \\
\hline $\begin{array}{l}\text { Lai and } \\
\text { Windawati } \\
(2017)\end{array}$ & $\begin{array}{l}\text { The volatility is higher around Ramadan for the } \\
\text { Indonesia stock market }\end{array}$ \\
\hline $\begin{array}{l}\text { Listyaningsih } \\
\text { and } \\
\text { Krishnamurti } \\
(2017)\end{array}$ & $\begin{array}{l}\text { This result was consistent with the theory in which } \\
\text { regarding to the bad news, investors will conduct more } \\
\text { transaction on risky stocks (Non-Sharia) to avoid loss. }\end{array}$ \\
\hline Lestari (2016) & $\begin{array}{l}\text { Conventional benchmark showed higher performance } \\
\text { compared with Islamic fund }\end{array}$ \\
\hline $\begin{array}{l}\text { Qomariah et al. } \\
\text { (2016) }\end{array}$ & $\begin{array}{l}\text { There are significant differences between the average } \\
\text { return and the conventional stock } \\
\text { mutual funds average return of sharia mutual fund } \\
\text { shares }\end{array}$ \\
\hline $\begin{array}{l}\text { Rumintang and } \\
\text { Azhari (2015) }\end{array}$ & $\begin{array}{l}\text { The performance of islamic fund is not diferrent with } \\
\text { conventional benchmarking }\end{array}$ \\
\hline $\begin{array}{l}\text { Hamzah and } \\
\text { Yohanes (2014) }\end{array}$ & $\begin{array}{l}\text { There is no different performance between islamic and } \\
\text { conventional benchmarking }\end{array}$ \\
\hline $\begin{array}{l}\text { Esha et al. } \\
(2014)\end{array}$ & $\begin{array}{l}\text { The study of sharia equity fund have better } \\
\text { performance and it could be compared with } \\
\text { conventional equity fund }\end{array}$ \\
\hline Ho et al. (2013) & $\begin{array}{l}\text { Islamic tend to similar performance to the conventional } \\
\text { benchmark. }\end{array}$ \\
\hline $\begin{array}{l}\text { Cahyaningsih et } \\
\text { al. (2009) }\end{array}$ & $\begin{array}{l}\text { The result showed Islamic fund tends to } \\
\text { underperformed compared to conventional benchmark. }\end{array}$ \\
\hline $\begin{array}{l}\text { Albaity and } \\
\text { Ahmad (2008) }\end{array}$ & $\begin{array}{l}\text { There is no significantly different risk-adjusted } \\
\text { return. However Islamic index are underperform than } \\
\text { conventional benchmark. }\end{array}$ \\
\hline $\begin{array}{l}\text { Ahmad and } \\
\text { Ibrahim (2002) }\end{array}$ & $\begin{array}{l}\text { Islamic index is really slightly lower than conventional } \\
\text { benchmark. }\end{array}$ \\
\hline $\begin{array}{l}\text { Ratnawati and } \\
\text { Khairani (2012) }\end{array}$ & $\begin{array}{l}\text { The performance of mutual funds, both Islamic and } \\
\text { conventional are different }\end{array}$ \\
\hline
\end{tabular}

\subsection{Islamic Investment}

The laws of economic Islam are clearly teaching based on the Holy Quran (the holy book of Muslims) and the Sunnah (the practices of the Prophet Muhammad). Islamic investment fund can be an instrument or might another reason why the 
investors to contribute their extra fund for the purpose of its investment to earn "Halal" profits that reliable with Shariah principles (Usmani, 2007).

There has been a growing desire to have funds in which profits are not based on riba, or interest, which is rejected in Islam. The Muslim faith deems that profit should come as a result of efforts; this is much more important than interest dominated in investment decision. In addition, there is a motivation for investment portfolios which are morally filtered. Thus investments in companies that do not comply with Muslims moral orientations are not permitted and are eliminated from the portfolio. To ensure compliance with the forgoing condition, Islamic mutual funds are governed by Shariah advisory boards whose role is mainly to give assurance that money is managed within the framework of Islamic laws (Hassan and Girard, 2011).

\subsection{Islamic Screening}

Islamic teachings are clearly prohibited in "Haram" (Forbidden) Principles. This is explained in the characteristic of Islamic screening. Islamic screening related to forbid bad activities such as alcohol, pork-related products, interest in conventional finance, gambling, pornography and other product that inconsistent with Islamic rule. Moreover, Indonesia Financial Services Authority explains about Maisir, Gharar and Riba. Maisir can be interpreted as gambling, every activity involving gambling and the party the gambling will take all the bets and the losing party will lose its bet. Gharar means any element of absolute or excessive uncertainty in any business or a contract that lead to a dispute. And Riba describe about an additional to the principal loan due to the time period element. In banking, it is called 'interest'.

Related in this study, Lobe et al. (2012) explain that the most of the index should consist with Islamic principles. The Islamic index is also should have an independent Shariah board to ensure Islamic index that listing in the capital market are consistent with Islamic principles. There are no activities of negative business that allowed in this Shariah index. Therefore, based on Islamic screening the index not applied Islamic principle will not included to the Islamic capital market.

\subsection{Islamic Index and Islamic Fund}

Islamic indices are offered mainly by the world's largest providers of financial market indices and banks. The first indices were introduced at the end of the 1990s. After the RHB (Rashid Hussein Bank) Islamic Index was launched in 1996, the Independent Global Index Company launched the FTSE Global Islamic Index Series in 1998, followed by the Dow Jones Islamic market index (DJIMI) in 1999, tracking the performance of Shariah compliant companies from 34 countries. At the moment, more than 400 Islamic indices exist at different levels (country, region, and worldwide), for example Credit Suisse HS50 Shariah Index, Dow Jones Islamic Market Index, Dubai Shariah Hedge Fund Index, FTSE Shariah Global Equity Index, Jakarta Islamic Index Indonesia, MSCI Barra Islamic Index, Kuala Lumpur Stock Exchage Shariah Index, MSCI Islamic Index etc (Lobe et al., 2012).

As well as more hundreds of variants there of (sector indices and indices with the same content in different currencies), these equity benchmark indices, designed to track the performance of leading publicly traded companies whose activities are consistent with the Shariah, cover more than 70 developed, emerging, and frontier markets, as well as the GCC (Gulf Cooperation Council) countries Bahrain, Kuwait, Oman, Qatar, Saudi Arabia, and United Arab Emirates. (Lobe et al., 2012) 
What are the differences in the composition of Islamic indices compared with conventional market indices? According to the MSCI Islamic Index Series Methodology, the equity portfolio of an Islamic index is initially based on the underlying conventional market benchmark but excludes all non-compliant securities in accordance with the principles of Shariah (the selection process is based on the criteria business activity and financial ratios. Specifically, companies are screened out that a reactive in order more than $5 \%$ of the revenues from business activities based on alcohol, tobacco, pork related products, conventional financial services, defence/weapons, gambling, or adult entertainment). In addition, firms with significant income from interest or excessive leverage are excluded (Walksh ̈̈Usl and Lobe, 2012)

\section{Conclusion}

Related to the previous studies, the Islamic studies showed inconsistency results, whether underperform, similar and outperform. According to the portfolio theory, Islamic fund is restricted by the Islamic law which is Islamic screening. This is the reason why Islamic tend to underperform. By focusing on comparative between Islamic funds against the benchmark fund, several results showed Islamic funds namely outperform, underperform, or similarly perform as well as compared to the conventional benchmark. This perspectives study is being concern because one of evidences showed Indonesia is the largest Muslim population in the world. Good investors who are not focuses on their return are expected change their mind to support this Islamic fund for their personal believe. Therefore, from the previous perspective this conceptual paper is expected giving new idea to the new empirical study in Indonesia and for the investor's decision. This study is also expected giving new perspective for the Islamic fund not only in capital market but also in mutual fund.

\section{References}

[1] ABDELSALAM, O., DUYGUN, M., MATALLÍN-SÁEZ, J. C. \& TORTOSAAUSINA, E. 2014. Do ethics imply persistence? The case of Islamic and socially responsible funds. Journal of Banking \& Finance, 40, 182-194.

[2] AHMAD, Z. \& IBRAHIM, H. 2002. A study of performance of the KLSE syariah Index. Malaysian Management Journal, 6 pp. 25-34.

[3] ALBAITY, M. \& AHMAD, R. 2008. Performance of Syariah and Composite Indices: Evidence from Bursa Malaysia. Asian Academy of Management Journal of Accounting and Finance, Vol. 4, 23-43.

[4] CAHYANINGSIH, C., SUWARDI, E. \& SETIAWAN, D. 2009. Perbandingan Kinerja Reksa Dana Syariah dengan Reksa Dana Konvensional. The Indonesian Journal of Accounting Research, 12.

[5] DEWI, M. K. \& FERDIAN, I. R. 2009. Evaluating performance of Islamic mutual funds in Indonesia and Malaysia. Retrieved March, 28, 2011.

[6] ESHA, M. R., HEYKAL, M. \& INDRAWATI, T. 2014. Analisis Perbandingan Reksa Dana Saham Syariah dengan Reksa Dana Saham Konvensional Periode 2009-2012. Binus Business Review, 5, 230-240.

[7] FORTE, G. \& MIGLIETTA, F. 2011. A comparison of socially responsible and Islamic equity investments. Journal of Money, Investment and Banking, 116132. 
[8] GHOUL, W. \& KARAM, P. 2007. MRI and SRI mutual funds: A comparison of christian, islamic (morally responsible investing), and socially responsible investing (SRI) mutual funds. The Journal of Investing, 16, 96-102.

[9] HAMZAH, A. \& YOHANES, A. 2014. Analisis Perbandingan Kinerja Reksa Dana Syariah Dengan Reksa Dana Konvensional Jenis Saham Pada Periode 2008-2012. MIX: Jurnal Ilmiah Manajemen, 4.

[10] HASSAN, M. \& GIRARD, E. 2011. Faith-based ethical investing: the case of Dow Jones Islamic indexes. Networks Financial Institute Working Paper, 06.

[11] HICKMAN, K. A., TEETS, W. R. \& KOHLS, J. J. 1999. Social investing and modern portfolio theory. American Business Review, 17, 72-78.

[12] HO, C. S. F., ABD RAHMAN, N. A., YUSUF, N. H. M. \& ZAMZAMIN, Z. 2013. Performance of global Islamic versus conventional share indices: International evidence. Pacific-Basin Finance Journal.

[13] HUDA, N. 2018. Simmiliarity Analisis Perbandingan Kinerja Reksa Dana Saham Syariah Dan Konvensional Periode 2012-2015. Repository YARSI.

[14] IDX, I. S. E. 2010. Buku Panduan Indeks Harga Saham Bursa Efek Indonesia [Online]. Available: http://www.idx.co.id/Portals/0/Information/ForInvestor/StockMarketIndicies/Fil eDownload/Buku\%20Panduan\%20Indeks\%202010.pdf.

[15] LAI, Y.-W. \& WINDAWATI, A. 2017. Risk, return, and liquidity during Ramadan: Evidence from Indonesian and Malaysian stock markets. Research in International Business and Finance, 42, 233-241.

[16] LESTARI, W. R. 2016. Kinerja Reksadana Saham Syariah Dan Reksadana Saham Konvensional. Jurnal Manajemen Magister Darmajaya, 1, 116-128.

[17] LISTYANINGSIH, E. \& KRISHNAMURTI, C. 2017. The Impact of Global Financial Crisis on Jakarta Islamic Index (JII): A Trading Volume Perspective. Advanced Science Letters, 23, 8197-8203.

[18] LOBE, S., RÖBLE, F. \& WALKSHÄUSL, C. 2012. The Price of Faith: Performance, Bull and Bear Markets, and Screening Effects of Islamic Investing Around the Globe. Journal of Investing, 21, 153-164.

[19] LYN, E. O. \& ZYCHOWICZ, E. J. 2010. The impact of faith-based screens on investment performance. The Journal of Investing, 19, 136-143.

[20] MARKOWITZ, H. 1952. Portfolio selection. The journal of finance, 7, 77-91.

[21] QOMARIAH, N., SARI, M. I. \& BUDIARTI, D. A. 2016. Perbandingan kinerja reksadana syariah dan reksadana konvensional (pada reksadana saham dan reksadana pendapatan tetap yang terdaftar di BEI periode 2010-2014). Jurnal Keuangan dan Perbankan, 20, 417-427.

[22] RATNAWATI, V. \& KHAIRANI, N. 2012. Perbandingan Kinerja Reksa Dana Syariah dan Reksa Dana Konvensional. Jurnal Akuntansi (Media Riset Akuntansi \& Keuangan), 1, 96-113.

[23] RUMINTANG, A. G. \& AZHARI, M. 2015. Analisis Perbandingan Kinerja Reksa Dana Saham Konvensional Dan Reksa Dana Saham Syariah Dengan Menggunakan Metode Sharpe, Treynor, Dan Jensen Pada Tahun 2014. eProceedings of Management, 2.

[24] SNOUSSI, J., SALAH, B. \& RIGOBERT, M. 2012. The Performance of Islamic Investment: Evidence from the Dow Jones Islamic Indexes. 
[25] SUNDORO, S. P. J. \& HANDAYANI, S. R. 2018. ANALISIS PERBANDINGAN KINERJA KEUANGAN REKSA DANA SYARIAH DI INDONESIA DAN DI ARAB SAUDI DENGAN METODE SHARPE, TREYNOR DAN JENSEN (Studi Pada Reksa Dana Saham Syariah Yang Terdaftar Di Otoritas Jasa Keuangan Dan Capital Market Authority Periode 2014-201. Jurnal Administrasi Bisnis, 65.

[26] USMANI, M. T. 2007. Principles of Shariah governing Islamic investment funds. Islamic Mutual Funds as Faith-Based Funds in a Socially Responsible Context.

[27] WALKSHÄUSL, C. \& LOBE, S. 2012. Islamic Equity Investing: Alternative Performance Measures and Style Analysis. Journal of Investing, 21, 182-189.

[28] ZULKAFLI, A. H., AHMAD, Z. \& ERMAL M, E. 2017. The Performance of Socially Responsible Investments in Indonesia: A Study of the Sri Kehati Index (SKI). Gadjah Mada International Journal of Business, 19, 59-76. 